\title{
The Proliferation Of Pawnshops And Check Cashing Outlets: Can Regulation Be To Blame?
}

\author{
Jill M. Hendrickson, (Email: jhendric@sewanee.edu), University of the South
}

\begin{abstract}
Regulation, particularly in banking, is often meant to protect the consumer. The Community Reinvestment Act, codified in 1977, was intended to protect low-income depositors by encouraging banks to extend loans to such depositors. Unfortunately, there are some important unintended consequences of the act that actually harm, rather than protect, low-income individuals. Using panel data from the first quarter of 2000, this paper illustrates that the implementation of the 1977 act may actually explain the growth in pawnshop and check cashing outlets both of which are extremely expensive forms of intermediation for consumers.
\end{abstract}

\section{Introduction}

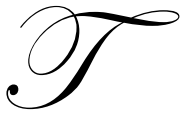

he 1977 Community Reinvestment Act (CRA) essentially requires commercial banks to make loans to those from whom it accepts deposits. This means that commercial banks or branch offices located in low-income communities who are accepting deposits from these individuals must also make loans to them. Not surprisingly, it is often unwise, from a risk perspective, for the bank to make such loans since the probability of repayment is so low. Consequently, it is possible that many banks and branches have closed their doors in low-income neighborhoods to avoid the CRA requirements. This means that many communities, particularly those in the most need financially, are without access to traditional commercial banks and the savings, payment, and credit opportunities associated with such institutions.

So, where do these people turn? One option is the growing alternative financial sector (AFS) which includes pawnshops, rent-to-own programs, refund anticipation loans, and check cashing outlets. ${ }^{1}$ Table 1 provides a brief summary of the different institutions that make up a large part of the AFS. Check cashing outlets have more than doubled since 1988, and today there are over 11,000 such stores in the United States. Moreover, these stores are no longer small, mom and pop stores. Rather, over one third of the stores are operated by six large companies and some of the stores are owned by the likes of GE Capital, Citibank, and Chase Manhattan (see Branch 1998). Pawnshop growth has been equally impressive as the number has more than doubled since 1985 (see Caskey 1994). However, this growth has not been evenly distributed throughout the United States. Instead, most of the growth has been in the South and Central Mountain regions. Unfortunately, these services are typically an extremely costly means of obtaining credit. Indeed, studies have found that annualized interest rates between 120 and 700 percent are not unusual.

Though certainly not the intent of the CRA, it has been hypothesized that the growth of the alternative financial sector may be traced to the act's enforcement (see, for example, Miller, Benjamin, and North (1999)). The purpose of this paper is to empirically test this hypothesis and, in the process, to try and understand the growth of the AFS. This is important because the AFS continues to grow and to provide important credit and payment services to those with low incomes, poor credit histories, and/or high debt to income ratios. Indeed, according to the Federal Reserve Board's Survey of Consumer Finances, 13 percent of all families in the United States in 1995 did not have a transaction (checking or savings) account at a mainstream financial institution. ${ }^{2}$ Thus a large segment of the population is relying on alternative sources for payments and credit; many of who turn to the AFS.

Readers with comments or questions are encouraged to contact the author via email. 


\section{Brief History of the Community Reinvestment Act}

The Community Reinvestment Act was codified on October 17, 1977 during the Carter administration and under the leadership of Senator William Proxmire (D-Wisc.). ${ }^{3}$ Senator Proxmire's passion for the legislation was aimed at eliminating the perceived practice of 'credit exportation' (Vern 1994). Credit exportation refers to the practice of taking deposited money from one community and using it to make loans in another community. The Senator and other lawmakers were convinced that such practices were unfair and required regulation, particularly in light of federal deposit insurance and charters granted to the banks practicing credit exportation.

Table 1.

Overview of the Alternative Financial Sector

\begin{tabular}{|l|l|}
\hline Institution & Description of Functions \\
\hline Pawnshops & $\begin{array}{l}\text { The customer typically leaves merchandise or an automobile title as collateral for } \\
\text { short-term loans usually not more than 30 days. }\end{array}$ \\
\hline Rent-to-Own & $\begin{array}{l}\text { The customer makes small rental payments for merchandise and the right to own } \\
\text { the merchandise at the completion of the contract. }\end{array}$ \\
\hline Check Cashing Outlets & $\begin{array}{l}\text { The customer is able to cash payroll and government checks for a fee based on the } \\
\text { location (state) of the outlet and the type of check. The customer may also be able } \\
\text { to cash post-dated checks for fees (up to two weeks). }\end{array}$ \\
\hline Refund Anticipation Loan & $\begin{array}{l}\text { The customer is able to secure a short-term traditional bank loan secured by the } \\
\text { customer's refund check from the IRS. }\end{array}$ \\
\hline
\end{tabular}

Source: Swagler, Burton, Lewis (1995).

The CRA requires that banks adequately service the credit needs of their local communities including the low and moderate-income neighborhoods. Regulatory agencies report on each institution's performance in meeting CRA provisions. Failure to meet the provisions is grounds to keep an institution from expansion or merging in the future. However, opponents of the CRA have always argued that such regulation will lead to forced credit allocation and unsound lending. Because of this opposition, lawmakers were reluctant to establish concrete 'rules' for banks to follow. Indeed, as Garwood and Smith $(1993,252)$ clearly establish,

(t)he act sets no criteria or guidelines for assessing the performance of an institution. It does not explain how an institutions 'community' should be selected, how credit needs are to be determined, how to define low- and moderate-income neighborhoods, or what constitutes satisfactory compliance.

Given the vagueness of the 1977 act, it is not surprising that during its first decade of existence, few knew of the regulation and regulators had trouble implementing it. In the late 1980s there was renewed enthusiasm for a more vigorous application of the CRA. In 1989 further legislation was passed requiring the regulatory agencies to disclose a financial institution's CRA ratings to the public and a more detailed framework was established for regulators and institutions. At the same time, the Federal Reserve denied an acquisition request on the basis of the acquiring bank's CRA report. ${ }^{4}$ This was the first time a regulatory agency utilized the CRA reports to deny an acquisition or merger.

As indicated by Vern (1994) and separately by Lacker (1995), the 1990s witnessed an acceleration in the use of the CRA and much of this attention may be credited to a 1992 study on mortgage lending bias by the Federal Reserve Bank of Boston. Though the study failed to find evidence of discrimination, it suggested that racial issues still played a role in lending practices. ${ }^{5}$ The study spurred renewed energy in the process of CRA examinations and the scrutiny by regulators of institutions' CRA performance records. Thus it really has only been the past decade, which coincides with much of the growth in the alternative financial sector, that the CRA has been vigorously enforced.

The CRA continues to be controversial today. ${ }^{6}$ Whether the CRA has been successful in ending credit exportation is open to debate as some argue it has accomplished a redistribution of funds to low-income communities 
(see, for example, Garwood and Smith (1993)). At the same time, others argue the act should be repealed as it has been ineffectual and simply acts as a government credit allocation program (see, for example, Vern (1994)). ${ }^{7}$ However, the point of this paper is not whether the CRA has been successful in reversing credit exportation but, rather, whether the CRA has inadvertently caused harm to those very people it was aimed to help by forcing low income individuals to utilize the more expensive alternative financial sector for their financial needs.

\section{Related Literature}

Contemporarily, John P. Caskey has completed the most extensive investigation into what he calls 'fringe' banking; a term coined by himself and Hyman Minsky to refer to check cashing outlets and pawnshops (Caskey 1994, xiii). In his 1994 book, Fringe Banking, Caskey offers a comprehensive discussion of the nature, history, growth, and regulation of pawnshops and of check cashing outlets. In the discussion of the growth in the industry, he hypothesizes that it may be traced to five factors; three from the demand side and two from the supply side. First, the decline in the ownership of traditional bank deposits has increased the demand for fringe bank services. Caskey finds this to be particularly true for low-income families. Rising credit risk among households may also increase the demand for fringe bank services as traditional commercial banks fail to service the increasing risky borrower. The third demand factor behind the growth in the AFS, according to Caskey, is the increase in immigration. New immigrants probably have a more difficult time obtaining commercial bank credit because of fewer savings and shorter employment records. On the supply side, Caskey argues that banks are making fewer unsecured personal loans thereby forcing some consumers into pawnshops or check cashing outlets. Finally, the growth in these institutions may also be attributable to the growing interest in the industry as a profitable business venture. The past decade has witnessed the expansion and birth of several national pawnshop and check cashing chains, which offer potentially large profits to entrepreneurs. ${ }^{8}$

In some of his earlier work, Caskey (1991) offers a comprehensive analysis of one sector within the AFS: the pawnshop industry. He argues that the growth in this particular sector may be explained by generous state usury laws that make the industry more profitable and by lower transportation costs that have led to the expansion of pawnshops in rural America. Thus, Caskey argues that regulation has played a role in the growth of the AFS; however, to Caskey it is insufficient interest rate regulation that has encouraged growth in the pawnshop industry. In discussing the expansion of the pawnshop industry specifically in the 1980s, Caskey and Zikmund (1990) attribute the growth to deregulation in banking which has meant higher service fees and minimum balances at commercial banks. These authors also argue that lower real wages and increased poverty rates may also explain the rise in the pawnshop industry in the 1980s.

Another important institution in the alternative financial sector, check-cashing outlets, is the focus of another Caskey (November/December 1991) study. He finds the 1980s growth of check cashing outlets (CCOs) to be closely tied to the growth of pawnshops. That is, since both institutions have similar clientele and both are alternatives to traditional commercial and savings banks, Caskey argues that their growth may be attributable to similar developments. More specifically, Caskey (November/December 1991) advances that declines in real income, higher bank fees, increased bank competition caused by deregulation, and the profitable business opportunities of the industry all explain the growth in the $\mathrm{CCO}$ segment of the alternative financial sector.

Caskey (June 1994) recognizes that banks close many branches located in low income areas but attributes these closings to competitive pressures between banks that resulted from deregulation in the early 1980s. ${ }^{9}$ Thus, according to Caskey, it is deregulation that increased competition between banks that led to the closure of less profitable branches in poorer communities. This study, in contrast, argues that regulation, in the form of the CRA, is what may have led to the closure of many of these banks and, in the process, opened the doors for pawnshops and cash checking outlet growth. In related literature, Swagler et al. (1995) also argue that the growth of the AFS may be attributable to deregulation in traditional banking which has resulted in higher fees on demand deposit accounts. They also suggest that rising income disparity has created a greater demand for AFS services.

Other relevant literature considers the motivation behind bank management decisions to change the number and/or location of branches and banks. Avery, Calem, and Canner (1997) theorize on reasons banks may decide to expand or contract their operations. These include the profitability of the office, risk diversification offered through 
an office, population changes of an area, technological change that may alter consumer preferences and/or efficiency at the bank, and deregulation and regulation that change the incentives for bank location. Interestingly, and in contrast to the ideas of this paper, Avery et al. (1997) argue that banks may choose to open new office in low-income neighborhoods in order to meet CRA standards. This idea, however, is in contrast to Caskey's (June 1994) finding that in several major cities banks have closed offices in low-income areas. It is also at odds another study which found, over a seven-year period, that most branch closing in New York City occurred in lower-income neighborhoods (Gross 1987).

There is also literature on the relationship between consolidation in banking and the availability of credit to low-income borrowers. This literature is almost exclusively related to mortgage lending. Avery, Calem, and Canner (1999) empirically examine the relationship between consolidation and home purchase lending and fails to find evidence that low-income and minority borrowers were credit squeezed. In fact, lending to these groups actually increased at a faster rate than higher-income borrowers in the 1990s. Though the authors hypothesize on why lending has increased to low-income and minority groups their hypothesis does not include crediting the provisions of the CRA.

\section{Data and Methodology}

Given data limitations at the state level it is not possible to perform a time series analysis which would be ideal to determine trends in the growth of pawnshops and check cashing outlets. It is possible, however, to collect cross sectional data and try to understand the number of such institutions and to infer, from those results, those factors which may have contributed to the growth of pawnshops and check cashing outlets.

According to Caskey (1994) there are two avenues for obtaining the necessary data. One is to contact all state regulation authorities and try to obtain numbers and regulation data from them. However, states are not consistently diligent in maintaining data records and some states are not even responsible for the supervision of pawnshops and check cashing outlets. Thus, state authorities can, at best, provide data on usury laws but typically cannot produce the number of such institutions in their states. The second option is to rely on private firms who compile lists of companies in the classifieds. Caskey (1994) argues that the numbers from classified listings and from state authorities tend to be comparable. Given these options, this paper relies on classified listing data compiled by Acxiom Corporation for the first quarter of 2000 to obtain the number of each type of institution in each state. State regulatory authorities are relied upon to provide usury law data or to indicate the appropriate regulatory authority from whom to obtain usury law information.

The models advanced in this paper are similar to that in Caskey (February 1991) and Caskey and Zikmund (1990). Caskey uses 1987 cross-sectional data of 28 states to see if the number of pawnshops per capita may be explained by interest rate and surplus regulation as well as state demographics. Interest rate regulation refers to the interest rate ceiling state authorities place on the rate pawnshops may charge for the collaterialized loan. Surplus regulation refers to the fact that some states require the pawnshop to return any surplus on the sale of collaterialized item to the borrower. State demographics include the percentage of the state population, over the age of twenty-five, who have a high school education; the population of the state; and the percentage of the population below the national poverty standard. He finds the interest rate regulation, poverty rates, and education rates to be statistically significant and of the expected sign.

This paper draws heavily from Caskey (February 1991) but also makes some important changes. Specifically, this model adds several important explanatory variables. ${ }^{10}$ It accounts for the implementation of the Community Reinvestment Act because scholars have suggested that the act has led to branch closures in low-income communities which, in turn, may explain the growing numbers of pawnshops and check cashing outlets. This model also considers median income as a possible explanatory factor in the growth of the AFS. Finally, this study differs from existing literature by considering the pawnshop industry alongside the check cashing outlets using cross-sectional data for the first quarter of 2000 for 47 states. ${ }^{11}$ Consequently, this model captures the broadest cross-sectional representation of these institutions in the United States. The linear models are specified as follows: 
(1) $P A W N_{i}=\beta_{0}+\beta_{1} I N T_{i}+\beta_{2} C R A_{i}+\beta_{3} E D_{i}+\beta_{4} P O P_{i}+\beta_{5} P O V_{i}+\beta_{6} I N C_{i}+\mu_{i}$

(2) $C A S H_{i}=\beta_{0}+\beta_{1} I N T_{i}+\beta_{2} C R A_{i}+\beta_{3} E D_{i}+\beta_{4} P O P_{i}+\beta_{5} P O V_{i}+\beta_{6} I N C_{i}+\mu_{i}$

with i denoting the state. Model (1) has as a dependent variable, PAWN, the number of pawnshops in each state during the first quarter of 2000 and model (2) has the number of check cashing outlets, CASH, as its dependent variable.

Two of the independent variables reflect relevant regulation. First, a set of dummy variables is created to control for differences in the monthly interest rate ceiling, INT, for the respective institution for each state. ${ }^{12}$ Since many of the states do not have interest rate ceilings, using specific interest rates as the independent variable would require omitting all states without ceilings. Instead, this model relies on multiple dummy variables to capture the different range of rate ceilings. These dummy variables were constructed at 5 percent intervals so that the first dummy is equal to one if the rate ceiling falls between 0 and 5 percent. The second is equal to one if the rate ceiling falls between 5.1 and 10 percent. The process continues so that the fifth dummy represents states with rate ceilings of 20 percent or greater and the sixth control represents states with no rate ceiling. This sixth dummy is also the control omitted from the regression to avoid multicollinearity problems. It is expected that those states with higher, or no, interest rate ceilings have larger numbers of pawnshops and check cashing outlets.

The second regulatory variable, CRA, controls for the implementation of the Community Reinvestment Act. As is often the case with regulatory measures, it is difficult to proxy such developments. In this case, the CRA is hypothesized to lead to a reduction in the number of banks and branches in low-income areas, so the model variable is the percentage decline in bank and branching units in each state. ${ }^{13}$ Recent empirical studies of bank closing have found that most closings are occurring in low income and minority neighborhoods (see Gross (1987) and Caskey (June 1994)). Banks close for a myriad of factors, though low profitability is certainly one possibility. CRA requirements reduce profitability. Indeed, according to a recent Federal Reserve study, loans made under the CRA provisions are unprofitable at a higher rate than average (Kulish 2000). Clearly not all closings are the result of the implementation of the act. However, the closings are an indication of banks' desire to extend profitable loans and, therefore, also an indication of banks' desire to avoid CRA requirements. It is expected that the greater the decline in commercial banks, the greater the need for some alternative financial institution and, consequently, the greater the number of pawnshops and check cashing outlets.

The remaining independent variables control for borrower characteristics that may make them more or less likely to demand the services of pawnshops and check cashing outlets. Following Caskey (February, 1991) and Caskey and Zikmund (1990), ED is the percentage of the state population, over age twenty-five, with a high school education and the percentage of the state population below the national poverty standard is represented as POV. Both the level of education and the percentage of the population in poverty are crude proxies for risk characteristics that may keep borrowers from mainstream financial institutions. POP is the population of the state. Following Avery, Calem, and Canner (1999) it is expected that the larger the state population, the greater the demand for the alternative financial institutions. INC captures the median household income for each state and it is expected that higher median income states will have fewer pawnshops and check cashing outlets, ceteris paribus.

\section{Results}

Table 2 contains the estimated results of both models. The adjusted coefficient of determination, for both models, indicates that the independent variables explain most of the variation in the dependent variable and suggest that the models are rather robust. Also, the Durbin-Watson statistics indicates that serial correlation is not present and no evidence of multicollinearity or heteroskedasticity is found.

Interestingly, though all estimated coefficients are of the expected sign, the only coefficient that is statistically significant in both the pawnshop and the check-cashing model is the CRA proxy. In both cases, the results suggest that the Community Reinvestment Act, as measured by the decline in commercial bank units, has encouraged the number of these alternative financial institutions. This is an important unintended consequence of regulation that intended to extend traditional financial services to lower-income consumers. The education, population, and income estimated coefficients are statistically 
Table 2.

Estimation Results

\begin{tabular}{|c|c|c|}
\hline & $\begin{array}{l}\text { PAWNSHOP } \\
\text { (Model 1) }\end{array}$ & $\begin{array}{c}\text { CHECK CASHING } \\
\text { (Model 2) }\end{array}$ \\
\hline constant & $\begin{array}{c}116.38 * * \\
(1.82)\end{array}$ & $\begin{array}{l}62.475 \\
(0.136) \\
\end{array}$ \\
\hline INT $0-5 \%$ & $\begin{array}{l}-7.437 \\
(1.02) \\
\end{array}$ & $\begin{array}{l}-9.751 \\
(1.52) \\
\end{array}$ \\
\hline INT $5.1 \%-10 \%$ & $\begin{array}{l}-3.763 \\
(0.51) \\
\end{array}$ & $\begin{array}{r}-9.001 \\
(1.58) \\
\end{array}$ \\
\hline INT $10.1 \%-15 \%$ & $\begin{array}{l}-1.807 \\
(0.203) \\
\end{array}$ & $\begin{array}{c}10.538 * * \\
(1.79)\end{array}$ \\
\hline INT $15.5 \%-20 \%$ & $\begin{array}{l}8.823 \\
(1.09) \\
\end{array}$ & $\begin{array}{l}7.245 \\
(0.543) \\
\end{array}$ \\
\hline INT $>20 \%$ & $\begin{array}{c}5.553 \\
(0.077)\end{array}$ & $\begin{array}{c}8.97 \\
(0.246)\end{array}$ \\
\hline CRA & $\begin{array}{l}0.406^{*} \\
(2.49) \\
\end{array}$ & $\begin{array}{c}1.011 * * \\
(1.86)\end{array}$ \\
\hline ED & $\begin{array}{c}-12.62 * * \\
(1.72) \\
\end{array}$ & $\begin{array}{l}-0.619 \\
(0.116)\end{array}$ \\
\hline POP & $\begin{array}{l}0.115^{*} \\
(2.68)\end{array}$ & $\begin{array}{c}0.014 \\
(0.428) \\
\end{array}$ \\
\hline POV & $\begin{array}{l}0.087 \\
(0.63) \\
\end{array}$ & $\begin{array}{l}0.413^{*} \\
(3.849) \\
\end{array}$ \\
\hline INC & $\begin{array}{l}-3.84 * \\
(2.78)\end{array}$ & $\begin{array}{l}-1.227 \\
(1.191)\end{array}$ \\
\hline Adjusted $\mathrm{R}^{2}$ & 0.667 & 0.897 \\
\hline DW statistic & 2.009 & 2.191 \\
\hline
\end{tabular}

Note: a $*$ and $* *$ denotes significance at the $5 \%$ and $10 \%$ level, respectively. Absolute values of the $\mathrm{t}$ statistic appear in parentheses.

significant in the pawnshop model while the poverty rate and interest rate control for the interest range $10.1-15$ percent is significant for the check cashing model.

These findings are, to some extent, at odds with the Caskey (February, 1991) findings. In particular, Caskey finds that the regulation on interest rates is significant in his model of pawnshops and concludes that the generous usury laws afforded by many states may explain the growth of these institutions, in part. This paper finds that the interest rates ceilings, or lack thereof, are generally not statistically significant in explaining the number of either pawnshops or check cashing outlets. This paper utilizes a broader sample of states than does Caskey, but what may explain the fact that the rate ceilings are not explaining the number of institutions? Once possible answer comes from how operators of these alternative financial institutions actually price their services, despite rate limits. Many discussions with state regulators indicate that typically, if the state has set an interest rate ceiling the pawn broker or check chasher will reconfigure their pricing structure to essentially earn an interest rate that is within the legal parameters but effectively much greater than the ceiling rate.

For example, in discussions with the state offices in Michigan, it is clear that check cashers legally meet the 7 percent interest rate limit but then add additional 'check cashing fees' to each transaction. Similarly, Missouri state code limits interest charges to 3 percent for pawnshops but, at the same time, allows the lender to charge for storage and security of personal property. According to the state's Division of Finance, this results in effective interest rates of 15 to 20 percent. Thus, while the rate charged for services will impact the profitability of the institution and is clearly important in determining the number of such institutions, the usury rates are not found to be statistically significant in and of themselves.

\section{Concluding Remarks}

This paper attempts to explain the growth of certain sectors of the AFS and considers the role of regulation in that growth. It finds that, despite its good intentions, the Community Reinvestment Act may have played a role in the growth of pawnshops and check cashing outlets. This is unfortunate since the act was intended to help lowincome borrowers and may have actually ended up hurting them. ${ }^{14}$

Does the future hold further growth of the AFS? Interestingly, there are already regulatory developments set into motion that may actually indirectly reverse this growth trend. During the 1990s two separate legislative acts were passed that establish electronic payment methods for many federal assistant programs. In 1996, the Personal Responsibility and Work Opportunity Reconciliation Act mandated that all food stamp benefits be delivered electronically by October 2002. Further, payments for those receiving assistance under the Temporary Assistance for Needy families program will also receive electronic payments. In addition to the payment of welfare benefits via electronic means, the 1996 Debt Collection Improvement Act requires that the Treasury make social security and other recurring federal benefits electronically. Taken together, these legislative developments may encourage those without traditional financial services to form more traditional banking relationships. Ultimately, should those currently utilizing the AFS decide to open demand deposits at commercial or savings banks because of these electronic 
payments it is possible that the growth trend of the AFS may witness a reversal of fortune. ${ }^{15}$

More recent market developments are also having an impact on the credit availability to low-income neighborhoods. Community Development Financial Institutions compete with the AFS for low-income financial business (Saunders and Stoesz 1998). ${ }^{16}$ Further, some scholars argue that with technological improvements and deregulation in commercial banking there is increased competition among lenders so that low-income borrowers are being served better today than in the past (see, for example, Gunther 2000). Indeed, Gunther (2000) finds that in 1997 approximately 40 percent of one to four family home loans extended in low-income neighborhoods originated from lenders not covered by the CRA. Despite these market developments, it is doubtful that the consumers of pawnshops and check cashing outlets will rely less on such institutions simply because a greater number of mortgage loans are extended to low-income borrowers. The daily transactions and payment system needs may still be unmet by traditional financial services in these neighborhoods which, in turn, has encouraged the growth of alternative financial sector institutions. And, according to the findings of this study, one explanation for this trend is the implementation of the Community Reinvestment Act.

\section{Endnotes}

${ }^{1}$ The term alternative financial sector is coined by Swagler, Burton, and Lewis (1995) and is meant to capture the notion that there are several different financial institutions that have similar clientele, all have experienced tremendous growth in the past two decades, and all serve the same general purpose. Swagler, Burton, and Lewis purposefully argue that this sector is an important aspect of the financial sector; one to be consider alongside of, and not outside of, traditional banking. Evidence that the AFS is replacing traditional banking comes from West Harlem where between 1987 and 1997 five commercial branch banks were closed while eight check cashing outlets were opened (Fontana 1997).

${ }^{2}$ Caskey and Petersen (1994) empirically attempt to explain why some households have bank accounts while other do not and found this to be explained largely by socioeconomic factors and not by deregulation that increased minimum balance requirements and account fees.

${ }^{3}$ For an interesting history of the events leading up to the 1977 Act, see Benston (1999).

${ }^{4}$ The Federal Reserve Board denied Continental Bank Corporation and Continental Illinois' bid to acquire Grand Canyon State Bank (Vern 1994, 27).

${ }^{5}$ It is important to note that, while the Fed study captured much attention, other scholarly work has failed to find a relationship between race and lending approval rates. See, for example, Schill and Watcher (1993), Benston (1995 and 1999), and Canner, Gabriel, and Wolley (1991). It is also interesting to note that Horne (1997) re-evaluated the Boston data and found serious mistakes that greatly change the results of the study.

${ }^{6}$ This controversy has been heightened by the passage of the 1999 Gramm-Leach Bliley Act which expanded the acceptable financial activities of bank holding companies. A House bill, the Community Reinvestment Modernization Act of 2001, proposes to extend CRA requirements to financial institutions outside of commercial banking, including securities firms, mortgage banks, insurance companies and other financial institutions.

${ }^{7}$ For another perspective, see Lacker (1995) who finds that there is little evidence to suggest that banks fail to meet the credit needs of poorer communities so that the CRA restrictions placed on banks are unwarranted.

${ }^{8}$ See Consumers Union (1998) for a discussion of the profitability of several large pawnshop franchises and companies.

${ }^{9}$ Caskey (June 1994) uses a statistical model to show that banks have closed branches in low-income and minority neighborhoods in several large cities. He finds that this trend is particularly true since 1980.

${ }^{10}$ In discussions with state regulators it was suggested, more than once, that another important factor in explaining the growth of these institutions is the growth in illegal immigration. Discussions with the INS indicate that state level data on the number of illegal immigrants is available for only 20 states, and then latest figures are for 1996. Consequently, this variable could not be added to these models. Another variable that could not be considered because of data limitations is consumer credit at the state level.

${ }^{11}$ Ideally, this model would use panel data over several years to capture the growth in these sectors. However, as was noted earlier, data on the number of such institutions over time is available only for a limited number of states. The only way to obtain the number of institutions across all states is to consider the most recent quarter. Certainly, from this point forward one could begin compiling this data for a panel study in the future. Three states, FL, NY, 
and $\mathrm{NC}$ have been omitted because decisions regarding interest rate ceilings are made at the municipal level in these states so it is not clear if ceilings exist across the state.

${ }^{12}$ In many states, the interest ceiling is a function of the amount of the pawn loan. In these cases, the interest rate reflects the rate on a three month loan between $\$ 50$ and $\$ 100$ since this is the most typical pawn loan amount according to Caskey (February, 1991). In the case of check cashing outlets, this interest rate reflects the charge for cashing personal checks only. The interest rate limit for state public assistance and for federal social security benefit checks is set at three percent.

${ }^{13}$ It is important to note that not all scholars advance a decline in the bank numbers when faced with CRA requirements. Indeed, Benston $(1999,10)$ argues that the Act discourages entry in to such areas: "... (the) CRA makes it almost impossible for banks to close branches in distressed neighborhoods. Although keeping such branches open might benefit some people, it has the unintended adverse effect of discouraging other regulated institutions from entering minority neighborhoods and offering banking services that might turn out to be unprofitable. Consequently, individuals who could benefit from checking, savings, consumer loans, and other banking services will be denied the convenience and benefits of competition by additional institutions." Because of this, the CRA variable was also proxied as the real dollar value of loans extended during the first quarter of 2000 and the regression results are not statistically different from the percentage decline in branch and bank units.

${ }^{14}$ Husock $(2000,36)$ argues that the CRA hurts those it was intended to help in another way as well. He says "(e)asy credit, by contrast, helps good neighborhoods become bad neighborhoods and bad neighborhoods stay that way much in the way that good, blue-collar neighborhoods are undermined when Section 8 housing voucher recipients are moved in, without having made the good life decisions - based on thrift, frugality, self-discipline and, yes, marriage - necessary to earn one's way to a better neighborhood."

${ }^{15}$ See Hogarth and O'Donnell (1999) for a discussion on how lower income families may change banking relationships as a result of these regulatory developments.

${ }^{16}$ Lacker (1995) discusses community development lenders and ultimately concludes that though they provide credit for home purchases to low income areas, they are not substitutes for commercial banks or for AFS institutions. The reason they are not seen as substitutes is because lending to low-income and minority borrowers requires special consideration when evaluating credit risk, securing funds, gaining knowledge of nontraditional measures of credit quality, and extensive monitoring of outstanding loans.

\section{References}

1. Avery, Robert B, Raphael Bostic, Paul Calem, and Glenn Canner (1997), "Changes in the Distribution of Banking Offices," Federal Reserve Bulletin 83 (September): 723.

2. (1999), "Trends in Home Purchase Lending: Consolidation and the Community Reinvestment Act," Federal Reserve Bulletin 85 (February): 81-102.

3. Benston, George (1999), "The Community Reinvestment Act: Looking For Discrimination That Isn't There," Policy Analysis, Cato Institute, (October).

4. _ _ (1995), "Mortgage Redlining Research," in Anthony M. Yezer ed., Fair Lending Analysis: A Compendium of Essays on the Use of Statistics, Washington D.C.: American Bankers Association: 144-95.

5. Board of Governors of the Federal Reserve System (1999), Annual Report to the Congress on Retail Fees and Services of Depository Institutions.

6. $\quad$ Branch, Shelly (1998), "Where Cash is King," Fortune, 137 (11) (June 8): 201.

7. Canner, Glenn B., Stuart A. Gabriel, and J. Michael Woolley (1991), "Race, Default Risk and Mortgage Lending: A Study of the FHA and Conventional Loan Markets," Southern Economic Journal 58 (July): 249-62.

8. Caskey, John P. (1991), "Pawnbrokering in America: The Economics of a Forgotten Credit Market," Journal of Money, Credit, and Banking, 23 (1) (February): 85-99.

9. (1991), "Cash-Checking Outlets in the U.S. Financial System," Federal Reserve Bank of Kansas City Economic Review, (November/December): 53-67.

10. (1994), "Bank Representation in Low-Income and Minority Urban Communities," Urban Affairs Quarterly, 29 (4) (June): 617-638.

11. _ (1994), Fringe Banking: Cash-Checking Outlets, Pawnshops, and the Poor, New York: Russell Sage Foundation.

12. Caskey, John P., and Andrew Petersen (1994), "Who Has a Bank Account and Who Doesn't," Eastern 
Economic Journal, 20 (1) (Winter): 61-74.

13. Caskey, John P., and Brian Zikmund (1990), "Pawnshops: The Consumer's Lender of Last Resort," Federal Reserve Bank of Kansas City Economic Review, (March/April): 5-17.

14. Consumers Union (1998), Our Neighborhood Banks: High Cost Loans for Low Income Borrowers, www.consunion.org/finance/nb2.htm.

15. Fontana, D. (1997), "Need Seen to Teach the Poor About High-Tech Banking," American Banker, (March 17).

16. Garwood, Griffith L., and Dolores S. Smith (1993), "The Community Reinvestment Act: Evolution and Current Issues," Federal Reserve Bulletin, 79 (4) (April): 251-67.

17. Gross, Laura (1987), "Branch Cuts Seen Hurting Minorities," American Banker, (February 23): 2.

18. Gunther, Jeffrey W. (2000), "Should CRA Stand for "Community Redundancy Act"?" Regulation, 23(3): 56-60.

19. Hogarth, Jeanne M., and Kevin O’Donnell (1999), “Banking Relationships of Lower-Income Families and the Governmental Trend Toward Electronic Payment," Federal Reserve Bulletin, 85 (7) (July): 459-73.

20. Horne, David K. (1996), "Mortgage Lending Race, and Model Specification," Journal of Financial Services Research, (March): 43-68.

21. Kulish, Nicholas (2000), "Bank Profit on CRA Loans Found to Be Lagging," Wall Street Journal, (July 18): A2.

22. Husock, Howard (2000), "Busting Up Neighborhoods," Forbes, (September 18): 36.

23. Lacker, Jeffrey M. (1995), "Neighborhoods and Banking," Federal Reserve Bank of Richmond, Economic Quarterly, 81 (2) (Spring): 13-38.

24. McKinley, Vern (1994), "Community Reinvestment Act: Ensuring Credit Adequacy or Enforcing Credit Allocation?," Regulation, 25-37.

25. Miller, Roger LeRoy, Daniel K. Benjamin, and Douglass C. North (1999), The Economics of Public Issues, Addison Wesley Publishing Inc.

26. Saunders, David and David Stoesz (1998), "Welfare Capitalism in a Global Economy: The American Experience," Virginia Commonwealth University, prepared for the Symposium on Financial Services in a PostWelfare-Reform Society, Federal Reserve Bank of Richmond, (April).

27. Schill, Michael H., and Susan M. Watcher (1993), "A Tale of Two Cities: Racial and Geographic Disparities in Home Mortgage Lending in Boston and Philadelphia," Working Paper 148, Wharton Real Estate Center (June 1).

28. Segar, Martha R. (1989), "Statement to the U.S. Senate Subcommittee on Consumer and Regulatory Affairs of the Committee on Banking, Housing, and Urban Affairs," Federal Reserve Bulletin, 75 (8) (August): 550-57.

29. Swagler, Roger, John Burton, and Joan Koonce Lewis (1995), "The Alternative Financial Sector: An Overview," Advancing the Consumer Interest 7 (2) (Fall): 7-12. 
Notes 


\footnotetext{
${ }^{1}$ The term alternative financial sector is coined by Swagler, Burton, and Lewis (1995) and is meant to capture the notion that there are several different financial institutions that have similar clientele, all have experienced tremendous growth in the past two decades, and all serve the same general purpose. Swagler, Burton, and Lewis purposefully argue that this sector is an important aspect of the financial sector; one to be consider alongside of, and not outside of, traditional banking. Evidence that the AFS is replacing traditional banking comes from West Harlem where between 1987 and 1997 five commercial branch banks were closed while eight check cashing outlets were opened (Fontana 1997).

${ }^{2}$ Caskey and Petersen (1994) empirically attempt to explain why some households have bank accounts while other do not and found this to be explained largely by socioeconomic factors and not by deregulation that increased minimum balance requirements and account fees.

${ }^{3}$ For an interesting history of the events leading up to the 1977 Act, see Benston (1999).

${ }^{4}$ The Federal Reserve Board denied Continental Bank Corporation and Continental Illinois' bid to acquire Grand Canyon State Bank (Vern 1994, 27).

${ }^{5}$ It is important to note that, while the Fed study captured much attention, other scholarly work has failed to find a relationship between race and lending approval rates. See, for example, Schill and Watcher (1993), Benston (1995 and 1999), and Canner, Gabriel, and Wolley (1991). It is also interesting to note that Horne (1997) re-evaluated the Boston data and found serious mistakes that greatly change the results of the study.

${ }^{6}$ This controversy has been heightened by the passage of the 1999 Gramm-Leach Bliley Act which expanded the acceptable financial activities of bank holding companies. A House bill, the Community Reinvestment Modernization Act of 2001, proposes to extend CRA requirements to financial institutions outside of commercial banking, including securities firms, mortgage banks, insurance companies and other financial institutions.

${ }^{7}$ For another perspective, see Lacker (1995) who finds that there is little evidence to suggest that banks fail to meet the credit needs of poorer communities so that the CRA restrictions placed on banks are unwarranted.

${ }^{8}$ See Consumers Union (1998) for a discussion of the profitability of several large pawnshop franchises and companies.
} 
${ }^{9}$ Caskey (June 1994) uses a statistical model to show that banks have closed branches in low-income and minority neighborhoods in several large cities. He finds that this trend is particularly true since 1980.

${ }^{10}$ In discussions with state regulators it was suggested, more than once, that another important factor in explaining the growth of these institutions is the growth in illegal immigration. Discussions with the INS indicate that state level data on the number of illegal immigrants is available for only 20 states, and then latest figures are for 1996. Consequently, this variable could not be added to these models. Another variable that could not be considered because of data limitations is consumer credit at the state level.

${ }^{11}$ Ideally, this model would use panel data over several years to capture the growth in these sectors. However, as was noted earlier, data on the number of such institutions over time is available only for a limited number of states. The only way to obtain the number of institutions across all states is to consider the most recent quarter. Certainly, from this point forward one could begin compiling this data for a panel study in the future. Three states, FL, NY, and $\mathrm{NC}$ have been omitted because decisions regarding interest rate ceilings are made at the municipal level in these states so it is not clear if ceilings exist across the state.

${ }^{12}$ In many states, the interest ceiling is a function of the amount of the pawn loan. In these cases, the interest rate reflects the rate on a three month loan between $\$ 50$ and $\$ 100$ since this is the most typical pawn loan amount according to Caskey (February, 1991). In the case of check cashing outlets, this interest rate reflects the charge for cashing personal checks only. The interest rate limit for state public assistance and for federal social security benefit checks is set at three percent.

${ }^{13}$ It is important to note that not all scholars advance a decline in the bank numbers when faced with CRA requirements. Indeed, Benston $(1999,10)$ argues that the Act discourages entry in to such areas: "... (the) CRA makes it almost impossible for banks to close branches in distressed neighborhoods. Although keeping such branches open might benefit some people, it has the unintended adverse effect of discouraging other regulated institutions from entering minority neighborhoods and offering banking services that might turn out to be unprofitable. Consequently, individuals who could benefit from checking, savings, consumer loans, and other banking services will be denied the convenience and benefits of competition by additional institutions." Because of this, the CRA variable was also proxied as the real dollar value of loans extended during the first quarter of 2000 and the regression results are not statistically different from the percentage decline in branch and bank units.

${ }^{14}$ Husock $(2000,36)$ argues that the CRA hurts those it was intended to help in another way as well. He says "(e)asy credit, by contrast, helps good neighborhoods become bad neighborhoods and bad neighborhoods stay that way much in the way that good, blue-collar neighborhoods are undermined when Section 8 housing voucher recipients are moved in, without having made the good life decisions - based on thrift, frugality, self-discipline and, yes, marriage - necessary to earn one's way to a better neighborhood."

${ }^{15}$ See Hogarth and O'Donnell (1999) for a discussion on how lower income families may change banking relationships as a result of these regulatory developments.

${ }^{16}$ Lacker (1995) discusses community development lenders and ultimately concludes that though they provide credit for home purchases to low income areas, they are not substitutes for commercial banks or for AFS institutions. The reason they are not seen as substitutes is because lending to low-income and minority borrowers requires special consideration when evaluating credit risk, securing funds, gaining knowledge of nontraditional measures of credit quality, and extensive monitoring of outstanding loans.

\section{References}

1. Avery, Robert B, Raphael Bostic, Paul Calem, and Glenn Canner (1997), "Changes in the Distribution of Banking Offices," Federal Reserve Bulletin 83 (September): 723.

2. (1999), "Trends in Home Purchase Lending: Consolidation and the Community Reinvestment Act," Federal Reserve Bulletin 85 (February): 81-102.

3. Benston, George (1999), "The Community Reinvestment Act: Looking For Discrimination That Isn't There," Policy Analysis, Cato Institute, (October).

4. _ _ (1995), "Mortgage Redlining Research," in Anthony M. Yezer ed., Fair Lending Analysis: A Compendium of Essays on the Use of Statistics, Washington D.C.: American Bankers Association: 144-95.

5. Board of Governors of the Federal Reserve System (1999), Annual Report to the Congress on Retail Fees and Services of Depository Institutions.

6. Branch, Shelly (1998), "Where Cash is King," Fortune, 137 (11) (June 8): 201. 
7. Canner, Glenn B., Stuart A. Gabriel, and J. Michael Woolley (1991), "Race, Default Risk and Mortgage Lending: A Study of the FHA and Conventional Loan Markets," Southern Economic Journal 58 (July): 249-62.

8. Caskey, John P. (1991), "Pawnbrokering in America: The Economics of a Forgotten Credit Market," Journal of Money, Credit, and Banking, 23 (1) (February): 85-99.

9. (1991), "Cash-Checking Outlets in the U.S. Financial System," Federal Reserve Bank of Kansas City Economic Review, (November/December): 53-67.

10. (1994), "Bank Representation in Low-Income and Minority Urban Communities," Urban Affairs Quarterly, 29 (4) (June): 617-638.

11. _ (1994), Fringe Banking: Cash-Checking Outlets, Pawnshops, and the Poor, New York: Russell Sage Foundation.

12. Caskey, John P., and Andrew Petersen (1994), "Who Has a Bank Account and Who Doesn't," Eastern Economic Journal, 20 (1) (Winter): 61-74.

13. Caskey, John P., and Brian Zikmund (1990), "Pawnshops: The Consumer's Lender of Last Resort," Federal Reserve Bank of Kansas City Economic Review, (March/April): 5-17.

14. Consumers Union (1998), Our Neighborhood Banks: High Cost Loans for Low Income Borrowers, www.consunion.org/finance/nb2.htm.

15. Fontana, D. (1997), "Need Seen to Teach the Poor About High-Tech Banking," American Banker, (March 17).

16. Garwood, Griffith L., and Dolores S. Smith (1993), "The Community Reinvestment Act: Evolution and Current Issues," Federal Reserve Bulletin, 79 (4) (April): 251-67.

17. Gross, Laura (1987), "Branch Cuts Seen Hurting Minorities," American Banker, (February 23): 2.

18. Gunther, Jeffrey W. (2000), "Should CRA Stand for “Community Redundancy Act"?" Regulation, 23(3): 56-60.

19. Hogarth, Jeanne M., and Kevin O’Donnell (1999), "Banking Relationships of Lower-Income Families and the Governmental Trend Toward Electronic Payment," Federal Reserve Bulletin, 85 (7) (July): 459-73.

20. Horne, David K. (1996), "Mortgage Lending Race, and Model Specification," Journal of Financial Services Research, (March): 43-68.

21. Kulish, Nicholas (2000), "Bank Profit on CRA Loans Found to Be Lagging,” Wall Street Journal, (July 18): A2.

22. Husock, Howard (2000), “Busting Up Neighborhoods,” Forbes, (September 18): 36.

23. Lacker, Jeffrey M. (1995), "Neighborhoods and Banking," Federal Reserve Bank of Richmond, Economic Quarterly, 81 (2) (Spring): 13-38.

24. McKinley, Vern (1994), "Community Reinvestment Act: Ensuring Credit Adequacy or Enforcing Credit Allocation?," Regulation, 25-37.

25. Miller, Roger LeRoy, Daniel K. Benjamin, and Douglass C. North (1999), The Economics of Public Issues, Addison Wesley Publishing Inc.

26. Saunders, David and David Stoesz (1998), "Welfare Capitalism in a Global Economy: The American Experience," Virginia Commonwealth University, prepared for the Symposium on Financial Services in a PostWelfare-Reform Society, Federal Reserve Bank of Richmond, (April).

27. Schill, Michael H., and Susan M. Watcher (1993), "A Tale of Two Cities: Racial and Geographic Disparities in Home Mortgage Lending in Boston and Philadelphia," Working Paper 148, Wharton Real Estate Center (June 1).

28. Segar, Martha R. (1989), "Statement to the U.S. Senate Subcommittee on Consumer and Regulatory Affairs of the Committee on Banking, Housing, and Urban Affairs," Federal Reserve Bulletin, 75 (8) (August): $550-57$.

29. Swagler, Roger, John Burton, and Joan Koonce Lewis (1995), "The Alternative Financial Sector: An Overview," Advancing the Consumer Interest 7 (2) (Fall): 7-12. 
Notes 